rosclerosis in rheumatoid arthritis. Arthritis Res. Ther. 2005;7(3):634-643. doi: 10.1186/ar1717

8. Elshabrawy H. A., Chen Z., Volin M. V., Ravella S., Virupannavar S. [et al.] The pathogenic role of angiogenesis in rheumatoid arthritis. Angiogenesis. 2015;18(4):433-448. doi: 10.1007/s10456-015-9477-2

9. Foster W., Shantsila E., Carruthers D., Lip G. Y., Blann A. D. Circulating endothelial cells and rheumatoid arthritis: relationship with plasma markers of endothelial damage/dysfunction. Rheumatology. 2009;48(3):285-288. doi: $10.1093 /$ rheumatology/ken486

10. Gonzalez-Gay M. A., Gonzalez-Juanatey C. Inflammation, endothelial function and atherosclerosis in rheumatoid arthritis. Arthritis Res. Ther. 2012;14:122. doi: 10.1186/ar3891

11. Gonzales-Gay M. A., Garcia-Unzueta M. T., de Matias J. M., Gonzalez-Juanatey C., Garcia-Porrua C. [et al.] Influence of anti-TNF-a infliximab therapy on adhesion molecules associated with atherogenesis in patients with rheumatoid arthritis. Clin. Exp. Rheumatol. 2006;24(4):373-379.

12. Gorska A., Kowal-Bielecka O., Urban M., Chlabicz S., Sienkiewicz J. [et al.] Impairment of microcirculation in juvenile idiopathic arthritis - studies by nail-fold videocapillaroscopy and correlation with serum levels of SICAM and VEGF. Folia Hystochem. Cytobiol. 2008;46(4):443-447. doi: 10.2478/v10042-008-0062-z

13. Klimek E., Skalska A., Kwaśny-Krochin B., Surdacki A., Sulicka J. [et al.] Differential associations of inflammatory and endothelial biomarkers with disease activity in rheumatoid arthritis of short duration. Mediators Inflamm. 2014;2014:681635. doi: org/10.1155/2014/681635

14. Klimiuk P. A., Fiedorczyk M., Sierakowski S., Chwiecko J. Soluble cell adhesion molecules (sICAM-1, sVCAM-1, and sE-selectin) in patients with early rheumatoid ar- thritis. Scand. J. Rheumatol. 2007;36(5):345-350. doi: $10.1080 / 03009740701406460$

15. Naranjo A., Sokka T., Descalzo M. A., Calvo-Alén J., Hørslev-Petersen K. [et al.] Cardiovascular disease in patients with rheumatoid arthritis: results from the QUEST_RA study. Arthritis Res. Ther. 2008;10(2):30. doi: $10.1186 / \operatorname{ar} 2383$

16. Navarro-Hernøndez R. E., Oregon-Romero E. VázquezDel Mercado M., Rangel-Villalobos H., Palafox-Sánchez C. A. [et al.] Expression of ICAM1 and VCAM1 serum levels in rheumatoid arthritis clinical activity. Association with genetic polymorphisms. Dis. Markers. 2009;26(3):119-126. doi: 10.3233/DMA-2009-0621

17. Pieringer $\mathrm{H}$. Pichler M. Cardiovascular morbidity and mortality in patients with rheumatoid arthritis: vascular alterations and possible clinical implications. QJM. 2011;104(1):13-26. doi: 10.1093/ajmed/hcq203

18. Puttevils D., De Vusser P., Geusens P., Dens J. Increased cardiovascular risk in patients with rheumatoid arthritis. Act Cardiol. 2014;69(2):111-118. doi: 10.2143/ AC.69.2.3017291

19. Rioja I., Hughes F. J., Sharp C. H., Warnock L. C., Montgomery D. S. [et al.] Potential novel biomarkers of disease activity in rheumatoid arthritis patients: CXCL13, CCL23, transforming growth factor alpha, tumor necrosis factor receptor superfamily member 9, and macrophage colony-stimulating factor. Arthritis Rheum. 2008;58(8):2257-2267. doi: 10.1002/art.23667

20. Shu Q., Amin M. A., Ruth J. H., Campbell P. L., Koch A. E. Suppression of endothelial cell activity by inhibition of TNF alpha. Arthritis Res. Ther. 2012;14(2):R88. doi: $10.1186 / \operatorname{ar} 3812$

21. Vestweber D. Adhesion and signaling molecules controlling the transmigration of leukocytes through endothelium. Immunol. Rev. 2007;218:178-196. doi: 10.1111/j.1600-065X.2007.00533.x

\footnotetext{
About authors:

Koroy Pavel Vladimirovich, MD, PhD, Professor of Department of Hospital Therapy; tel.: +79282938068; e-mail: paule75@yandex.ru Sarithala Vidjaya, MD, Post-Graduate Student of Department of Hospital Therapy; tel.: +79887422198; e-mail: jay_sv2006@yahoo.com Yagoda Alexander Valentinovich, MD, PhD, Professor, Honored Worker of Science of Russian Federation, Head of Department of Hospital Therapy; tel.: +78652295309; e-mail: alexander.yagoda@gmail.com

\title{
SOME PECULIARITIES OF ACUTE MYOCARDIAL INFARCTION PATHOGENESIS IN NON-OBSTRUCTIVE CORONARY ARTERIES
}

\author{
Dyatlov N. V., Lykov Yu. V., Zhelnov V. V., Dvoretsky L. I.
}

First Moscow State Medical University, Russian Federation

\section{НЕКОТОРЫЕ ОСОБЕННОСТИ ПАТОГЕНЕЗА ОСТРОГО ИНФАРКТА МИОКАРАА ПРИ НЕОБСТРУКТИВНОМ ПОРАЖЕНИИ КОРОНАРНЫХ АРТЕРИЙ}

\author{
Н. В. Аятлов, Ю. В. Аыков, В. В. Желнов, А. И. Аворецкий
}

\section{Первый Московский госуАарственный меАицинский университет им. И. М. Сеченова, Российская ФеАерация}

Myocardial infarctions (MI) in case of non-obstructive atherosclerosis or intact coronary arteries are set apart into a separate group - myocardial infarction with no-obstructive coronary atherosclerosis - MINOCA. 1240 patients were included. The first group comprised the patients with single-vessel disease and complete acute occlusion - 
infarction of the responsible coronary artery (myocardial infarction with obstructive coronary atherosclerosis - MIOCA) $21.9 \%$. The second group comprised the patients with MINOCA $7.7 \%$. The average age of patients in Group 1 was $56.59 \pm 11.6$ years, in Group 2 it amounted to $67.9 \pm 11.5(p<0.001)$. Diabetes, CKD, exertional angina, symptoms of CHF and arterial hypertension were more likely for patients with MINOCA as compared to MIOCA - $20.8 \%$ vs $7.4 \%$ $(p<0.05), 25.0 \%$ vs $11.8 \%$ ( $p<0.05), 29.2 \%$ vs $14.7 \%(p<0.05), 41.7 \%$ vs $17.6 \%(p<0.05) 91.7 \%$ vs $72.1 \%$ $(p<0.01)$ respectively. Several mechanisms of myocardial necrosis were discussed: plaque disruption without the obstruction of coronary artery lumen and/or spontaneous thrombolysis, spontaneous intima dissection, infection, myocardial bridge, vasospasm. Thus, the pathogenesis of necrosis in patients with MINOCA is ambivalent and one patient may have combination of various pathogenic mechanisms, which makes the process of diagnostics and the selection of adequate treatment more complicated.

\section{Keywords: myocardial infarction, non-obstructive coronary atherosclerosis, intact coronary arteries}

Инфаркт миокарда (ИМ) при необструктивном атеросклерозе или при интактных коронарных артериях выделен в отдельную группу - MINOCA (Myocardial infarction with no obstructive coronary atherosclerosis). B исследование включено 1240 пациентов. Первую группу составили пациенты с однососудистым поражением и полной острой окклюзией инфаркт-связанной коронарной артерии - 21,9%. Вторую группу составили пациенты с острым инфарктом миокарда и необструктивным поражением коронарных артерий (стеноз менее

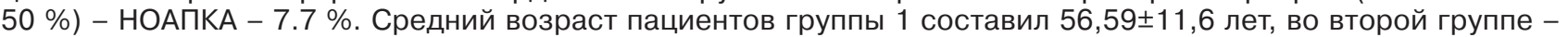
$67,9 \pm 11,5$ лет (р<0.001). Сахарный диабет, ХБП, стенокардия напряжения, симптомы ХСН, артериальная гипертензия были более характерны для пациентов группы 2 по сравнению с группой 1: 20,8 и 7,4 \% (p<0,05), $25,0$ и 11,8 \% (p<0,05), 29,2 и 14,7 \% (p<0,05), 41,7 и 17,6 \% ( $p<0,05), 91,7$ и 72,1 \% ( $(<<0,01)$ соответственно. Рассмотрены некоторые механизмы развития некроза миокарда у пациентов с НОАПКА: нарушение целостности атеросклеротической бляшки без обструкции коронарной артерии и/или спонтанный тромболизис, спонтанная диссекция интимы, инфекция, миокардиальный мостик, вазоспазм. Патогенез ИМ при необструктивном поражении коронарных артерий неоднозначен, и у одного пациента могут сочетаться несколько вариантов, что затрудняет диагностику и подбор адекватной терапии.

Ключевые слова: инфаркт миокарда, необструктивный атеросклероз коронарных артерий, интактные коронарные артерии

C oronary angiography (CA) is the "gold standard" of Ischemic Heart Disease (IHD) diagnostics, which serves to identify atherosclerotic coronary artery disease (CAD). However, with the introduction of this method into practice, detection of slightly defected or intact coronary arteries has become rather common in the presence of proven acute myocardial infarction (AMI). Up to date, many forms of myocardial infarction pathogenesis have been described for non-obstructive and/or intact coronary arteries: vasospasm and endothelial dysfunction, coronary embolism, etc. The reality is that not all individual pathogenetic variants of this type of MI type may be classified based on universal classification of the III Universal Definition. Therefore, MIs in case of non-obstructive atherosclerosis are set apart into a separate group - MINOCA (Myocardial infarction with no obstructive coronary atherosclerosis). In accordance with guidelines of the European Society of Cardiology Working group, this part comprises cases of proven MI based on the III Universal definition with normal and/or subnormal CAD (atherosclerotic stenosis of less than $\mathbf{5 0} \%$ ) among patients with CA [1]. Such clinical cases are revealed in $3 \%$ to $25 \%$ of the total number among patients with MI [2, 3, 5]. Such ambivalent results are conditioned by differences in the design of the conducted studies, peculiarities of criteria for inclusion, and selection of experimental groups. Despite a reasonably large amount of literature data regarding this group of $\mathrm{MI}$, such cases involve some or other difficulties in clinical practice, particularly, from the attempts to determine MI pathogenesis on down to choosing adequate therapy, which is specifically conditional upon the lack of unified concept as to clinical interpretation of the given group of patients.

The aim of study: to determine the most probable pathogenetic variants of the given type of MI (MINOCA) among the examined patients
Material and Methods. Patients with MI hospitalized in the Resuscitation and Intensive Care Unit of State Budget Health Care Institution Moscow Municipal Clinical Hospital named after S.S. Yudin with the diagnosis «primary acute myocardial infarction» during the period from 2015 through 2016, to which CA was performed within 90 minutes from to the moment of hospitalization, were included into the study. The first group comprised the patients with single-vessel disease and complete acute occlusion - infarction of the responsible coronary artery (myocardial infarction with obstructive coronary atherosclerosis - MIOCA), i. e. atherothrombosis was the only possible mechanism for the development of myocardial ischemia. The second group comprised the patients with acute myocardial infarction with noobstructive coronary atherosclerosis (coronary stenosis of less than $50 \%$ ) - MINOCA, i.e. with potentially multifactorial mechanism of development of acute myocardial ischemia. MI was diagnosed based on the III Universal definition [18]

Physical examination was carried out for all patients in accordance with conventional methodology, ECG was registered in 12 standard leads by using a device from Schiller company (Germany). General blood test (SWELAB device, INSTRUMENT AUTO COUNTER AC 920), biochemical blood test (Automatic Biochemistry Analyzer - Liasys, Ellips, SAT 450) were performed upon admission. Test system «C1101r RAMP Troponin l» was used to determine Tnl. CA was carried out using a device «Innova 3100» (GE, Germany) equipped with a program for quantitative analysis. Angiographic studies were performed using Seldinger's method through radial or femoral arterial access. Five standard projections for the left main coronary artery (LMCA) and 2 standard projections for the right coronary artery $(R C A)$ were used in the study of coronary arteries. Within a year of discharge from the hospital, the patients were contacted by way of phone calls in order to clarify the issues regarding systematic consumption of the prescribed drugs, 
repeated ischemic events, repeated hospitalizations and symptoms of exertional angina. The study was carried out in accordance with the Helsinki Declaration, it was approved by the Ethics Committee, all participants signed informed consent. In order to process the data received, a standard package for Windows 10 was used: Microsoft Word 2016, Microsoft Excel 2016. A standard IBM SPSS Statistics 23.0 application package was used to perform statistical analysis. Generally accepted methods of processing statistical data were applied. All quantitative indicators were verified with regard to normal distribution using the test of Kolmogorov-Smirnov. Quantitative indicators with normal distribution are presented as average values \pm standard deviation $(\mathrm{M} \pm \sigma)$, and quantitative indicators with abnormal distribution are presented as a median and $95 \%$ credible interval $(\mathrm{CI})$. Distributions for the groups were compared automatically with the use of Mann-Whitney U criterion for two samples, or the one-way variance analysis of Kruskal-Wallis for $\mathrm{K}$ samples (depending on data). Comparison of the groups by qualitative characteristics was carried out using the construction of contingency tables with the subsequent application of Pearson's method (if the sum of the frequencies was more than 40, continuity-corrected criterion was applied). If the sum of the frequencies was less than 20, Fisher's exact test was applied.

Results and Discussion. Within the first 90 minutes after hospitalization, CA was applied with regard to1240 patients diagnosed with AMI. Among them, single-vessel disease with complete acute CA occlusion (group 1) was detected in $21.9 \%$ of cases, non-obstructive lesions in coronary arteries (group 2) were detected in $7.7 \%$ of cases. Otherwise $(70.4 \%)$, lesions in two or more arteries were revealed. The average age of patients in Group 1 was $56.59 \pm 11.6$ years, in Group 2 it amounted to $67.9 \pm 11.5(p<0.001)$. Gender distribution between the groups was significantly different (in Group $1-67.6 \%$ of men and $32.4 \%$ of women, as compared to $45.8 \%$ of men and $54.2 \%$ of women in Group 2, p<0.01).

When comparing data on anamnesis in patients with MI (Table 1), some significant differences were revealed (Figure).

Table 1

Patients with Myocardial Infarction Comorbidieties

\begin{tabular}{|l|c|c|c|}
\hline \multicolumn{1}{|c|}{ Indicator } & $\begin{array}{c}\text { Group 1 } \\
\text { (MIOCA) }\end{array}$ & $\begin{array}{c}\text { Group2 } \\
\text { (MINOCA) }\end{array}$ & $\begin{array}{c}\text { Significance } \\
\text { of Differences } \\
(\mathrm{p})\end{array}$ \\
\hline Smoking & $59.1 \%$ & $29.2 \%$ & $<0.01$ \\
\hline Diabetes Mellitus & $7.4 \%$ & $20.8 \%$ & $<0.05$ \\
\hline CKD & $11.8 \%$ & $25 \%$ & $<0.05$ \\
\hline COPD & 11.8 & $20.8 \%$ & $>0.05$ \\
\hline ACD & $4.4 \%$ & $8.3 \%$ & $>0.05$ \\
\hline $\begin{array}{l}\text { Arterial } \\
\text { hypertension }\end{array}$ & $72.1 \%$ & $91.7 \%$ & $<0.01$ \\
\hline $\begin{array}{l}\text { Symptoms of ex- } \\
\text { ertional angina be- } \\
\text { fore hospitalization }\end{array}$ & $14.7 \%$ & $29.2 \%$ & $<0.05$ \\
\hline Symptoms of CHF & $17.6 \%$ & $41.7 \%$ & $<0.01$ \\
\hline $\begin{array}{l}\text { AF in past medical } \\
\text { history }\end{array}$ & $11.3 \%$ & $37.5 \%$ & $<0.01$ \\
\hline
\end{tabular}

The note: CKD - Chronic Kidney Disease; COPD - Chronic Obstructive Pulmonary Disease; ACD - Acute Cerebrovascular Disorder; AF - Atrial Fibrilation.

It should be noted that among the patients the paroxysmal AF was found in $7.4 \%$ in Group 1 vs. $29.2 \%$ in Group $2(p<0.05)$, and permanent form of AF in $2.9 \%$ vs. $8.3 \%(p>0.05)$.

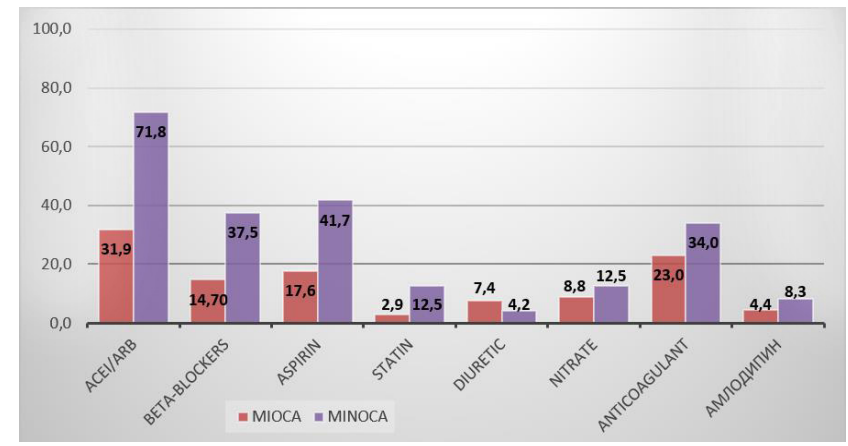

Fig. Peculiarities of ambulant therapy in patients with MI before hospitalization

The ECG pattern analysis at the time of admission among examined patients revealed a number of peculiarities (Table 2).

Table 2

ECG Pattern in Patients with Myocardial Infarction

\begin{tabular}{|l|c|c|c|}
\hline \multicolumn{1}{|c|}{ Indicator } & $\begin{array}{c}\text { Group 1 } \\
\text { (MIOCA) }\end{array}$ & $\begin{array}{c}\text { Group 2 } \\
\text { (MINOCA) }\end{array}$ & $\begin{array}{c}\text { Significance } \\
\text { of Differences } \\
(\mathrm{p})\end{array}$ \\
\hline Pathologic Q wave & $57.4 \%$ & $12.5 \%$ & $<0.001$ \\
\hline $\begin{array}{l}\text { ST-segment } \\
\text { elevation }\end{array}$ & $76.5 \%$ & $37.5 \%$ & $<0.01$ \\
\hline $\begin{array}{l}\text { ST-segment } \\
\text { depression }\end{array}$ & $11.8 \%$ & $29.2 \%$ & $<0.05$ \\
\hline $\begin{array}{l}\text { Non-specific ST } \\
\text { variation }\end{array}$ & $11.8 \%$ & $33.3 \%$ & $<0.01$ \\
\hline TLBB & $1.5 \%$ & $8.3 \%$ & $>0.05$ \\
\hline $\begin{array}{l}\text { Availability of any } \\
\text { blockade in HBB } \\
\text { system }\end{array}$ & $12 \%$ & $30 \%$ & $<0.05$ \\
\hline
\end{tabular}

The note: TLBB - total left bundle block; HBB - the His bundle branch.

The analysis of MI localization based on ECG data revealed some differences. In the group of patients with MINOCA, $13.0 \%$ of patients with unspecified MI localization were identified, whereas in the group of patients with MIOCA, no such patients were revealed. In other cases, the following was determined: anterior localization of $\mathrm{MI}(30.4 \%$ vs. $32.4 \%, \mathrm{P}>0.05)$, posterior localization of MI (4.3\% vs. $9.1 \%, p>0.05)$, anteroposterior localization of $\mathrm{MI}(4.3 \%$ vs. $9.1 \%$, p $>0.05$ ), anterolateral localization (21.7\% vs. $16.7 \%$, $\mathrm{p}>0.05)$, lower-lateral localization (17.4\% vs. $9.6 \%$, $\mathrm{p}>0.05$ ), lower MI localization (8.7\% vs. $23.2 \%, p<0.05$ ).

Among the symptoms of myocardial ischemia in Groups 1 and 2, «classical» chest pain was predominant ( $89.7 \%$ vs. $54.2 \%, p<0.01)$, dyspnea was revealed in $2.9 \%$ and $8.3 \%$ of patients ( $p>0.05)$, respectively. It should also be noted that patients in Group 2, the socalled nonspecific symptoms were revealed significantly more often - dizziness, headache, general weakness, palpitations ( $7.4 \%$ vs. $37.5 \%, \mathrm{p}<0.01$, respectively), which basically are not the symptoms of myocardial ischemia according to the III Universal definition [18]. It is apparently due to this reason that Group 2 patients were characterized by later hospitalization as compared to Group 1 patients ( 3 hours, $95 \% \mathrm{Cl}$ 2; 4 versus 6 hours, $95 \% \mathrm{Cl} 4 ; 7, \mathrm{p}<0.05)$. Moreover, at the time of collecting detailed past medical history, some patients with both obstructive (23\%) and non-obstructive (78 \%) lesions in coronary arteries described the so-called «aura», i.e. they noted general feeling unwell without a distinct clinical picture a few hours before the occurrence of 
major symptoms $(17.1 \pm 4.3$ hours vs. $47.6 \pm 11.4$ hours, $p<0.01$, respectively).

When analyzing standard plasma biochemical indicators, significant differences were revealed only in concentration of lactate dehydrogenase (LDH) and aspartate aminotransferase (AST): $833.6 \pm 134.2$ vs. $433.9 \pm 309.1(p<0.01) ; 142.0 \pm 99.4$ vs. $60.9 \pm 13.5(p<0.05)$, respectively. Conspicuous is the fact that concentration of total plasma cholesterol in Group 1 and Group 2 patients did not differ significantly (5.7 \pm 1.5 and $5.3 \pm 1.2, p>0.05$, respectively), although patients with MINOCA administered statins significantly more often. In addition, general blood test revealed significant differences in concentration of leukocytes $\left(11.07 \pm 3.9^{*} 10^{\wedge} 9\right.$ vs. $\left.8.7 \pm 2.9^{*} 10^{\wedge} 9, p<0.05\right)$, hemoglobin (145.2 \pm 14.1 vs. $136.4 \pm 17.4 \mathrm{~g} / \mathrm{l}, \mathrm{p}<0.05)$, respectively. Thrombocyte count in the peripheral blood did not differ significantly.

Recommendations were also analyzed with regard for further ambulant treatment as to patients with $\mathrm{Ml}$ at the time of discharge from the hospital (Table 3).

Recommendations for Further Ambulant Therapy

\begin{tabular}{|l|c|c|c|}
\hline \multicolumn{1}{|c|}{ Indicator } & $\begin{array}{c}\text { Group 1 } \\
(\text { MIOCA) }\end{array}$ & $\begin{array}{c}\text { Group 2 } \\
(\text { MINOCA) }\end{array}$ & $\begin{array}{c}\text { Significance } \\
\text { of Differences } \\
(\mathrm{p})\end{array}$ \\
\hline Aspirin & $100 \%$ & $87.5 \%$ & $<0.05$ \\
\hline $\begin{array}{l}\text { Clopidogrel } \\
\text { or ticagrelor }\end{array}$ & $100 \%$ & $91.7 \%$ & $<0.05$ \\
\hline $\begin{array}{l}\text { Warfarin } \\
\text { or NOADs* }\end{array}$ & $7.4 \%$ & $12.5 \%$ & $>0.05$ \\
\hline Statins & $98.5 \%$ & $91.7 \%$ & $>0.05$ \\
\hline Beta-blockers & $97.1 \%$ & $91.7 \%$ & $>0.05$ \\
\hline ACEI or ARB & $76.5 \%$ & $83.4 \%$ & $<0.05$ \\
\hline Loop diuretic & $17.6 \%$ & $25.0 \%$ & $>0.05$ \\
\hline $\begin{array}{l}\text { Calcium-channel } \\
\text { blocker }\end{array}$ & $0 \%$ & $25.0 \%$ & - \\
\hline
\end{tabular}

*NOADs - new oral anticoagulant drugs.

The examined patients have been followed up within one year after their discharge from the hospital. The loss of follow-up (complete absence of data about a patient) was at the level of $35 \%$ in Group 1, and $23 \%$ in Group 2. Unfortunately, low degree of adherence to treatment was observed in both groups: Aspirin treatment $83.3 \%$ vs $60 \%(p<0.01)$, ACEI/ARB $58.3 \%$ vs $70 \%$ ( $p>0.05)$, betablockers $60 \%$ vs $80 \%(p<0.05)$, clopidogrel/ticagrelor $58.3 \%$ vs $20 \%(p<0.01)$, statin $58.3 \%$ vs $80 \%(p<0.01)$ in Groups 1 and 2 respectively.

A year after discharge from the hospital, cases of repeated hospitalization ( $25 \%$ vs. $33.3 \%, p<0.05$ ), as well as those of recurrent coronary events, repeated CA $(7.7 \%$ vs. $2 \%, p>0.05)$, clinical manifestations of exertional angina ( $3.5 \%$ vs. $45 \%, p<0.01$ ) were observed.

The results of our study and the data available in literature allow us to discuss probable pathogenetic mechanisms of development of myocardial necrosis in patients with MINOCA. For the moment, several main pathogenetic variants are being reviewed:

1. Atherosclerotic plaque disruption without the obstruction of CA lumen. These cases include erosion, ulceration of plaques, hemorrhages. The studies conducted using intravascular ultrasound imaging method showed that, according to CA data, in $40 \%$ cases of $\mathrm{MI}$ with non-obstructive lesions in coronary arteries the above morphological changes of atherosclerotic plaque in infarction-related artery are revealed $[12,14]$. In addition, cases have been described involving calcified tectum thrombosis of atherosclerotic plaque without disruption of its continuity and without obstruction of artery lumen [7]. In our opinion, such cases are more characteristic of elderly patients who systematically administer statins, which results in the reduction in atherosclerotic plaque size [11]. Since our study was not based on the application of intravascular ultrasound imaging method, and CA was not the relevant method for diagnosing nonstructural integrity disorders of atherosclerotic plaque and much less hemorrhages in them, it is impossible to indicate what is the exact number of patients from Group 2 that might have this pathogenetic mechanism of IM development. However, with due regard to the fact that average age of Group 2 patients was significantly higher (67.9 \pm 11.5 vs. $56.59 \pm 11.6, p<0.001)$, we found out that hypercholesterolemia in this group significantly didn't differ from Group 1 patients ( $5.3 \pm 1.2$ vs. $5.7 \pm 1.5 p>0.05)$, whereas statins were administered more often $(12.5 \%$ vs. $2.9 \%, p<0.05$ ) by Group 2 patients before they were hospitalized, apparently, this category of patients with MINOCA probably may be an example of this particular pathogenetic mechanism.

2. Spontaneous thrombolysis. According to the data stated in literature, patients with the ST-segment elevation myocardial infarction (STEMI) in 17-32\% of cases experience spontaneous opening of infarctionrelated artery within 4 hours from the occurrence of pain attack [16]. The episodes of the preceding myocardial ischemia (exertional angina) are important for pathogenesis of spontaneous thrombolysis [17]. In our study, ST-elevation in patients with non-obstructive lesions in coronary arteries was revealed in $37.5 \%$ of cases, and ST depression - in only $29.7 \%$ of cases (insignificant differences). At that, stable exertional angina in past medical history of such patients was revealed 2 times as often as compared to patients from MIOCA group. Unfortunately, preadmission period for Group 2 patients was too long in general to assess the availability of spontaneous thrombolysis (on the average, 18.16 hours as compared to 6.59 hours in Group 1) using objective methods.

3. Spontaneous coronary artery dissection. Being an extremely rare cause of myocardial infarction, although found in $50 \%$ of cases, spontaneous dissection of intima may be a cause of a sudden cardiac death. At that, this phenomenon is observed both in intact coronary arteries and in arteries affected by atherosclerosis of varying severity [8]. In our study, such a mechanism of development of myocardial infarction has not been revealed, although combinations of vasospasm and spontaneous dissection of intima have been described in literature [19].

4. Infection. For the time being, a large body of evidence has been gathered that convincingly proves the existence of interrelation between infection and cardiovascular pathology. It was shown that elevated markers of inflammation (for example, C-reactive protein, especially highly sensitive) in healthy subjects are independent predictors of development of coronary heart disease. Chlamydia pneumoniae, Cytomegalovirus are basic infectious agents that are currently considered as potential inducers of complications in the form of ACS. In addition, it is very difficult to prove interrelation between recent infection and a coronary event, apparently it is for this very reason that there are no detailed statistical data on the occurrence of this phenomenon [8]. Due to lack of generally accepted diagnostic algorithm, we did not consider this mechanism of MI development in our study. Suffice it to point out that a significantly higher concentration of leukocytes (leukocytosis) was found in 
our study in a group of patients with MIOCA as compared to the group of patients with non-obstructive lesions in coronary arteries, where the concentration of leukocytes in peripheral blood remained normal. In our opinion, leukocytosis itself may hardly bear evidence of the infectious genesis of atherosclerotic plaque thrombosis. There is every likehood that it is a testimony to nonspecific response to a coronary event.

5. Concealed atherosclerosis. Sophisticated imaging methods made it possible to diagnose in vivo two different types of arterial sclerotic diseases: growing inward a vessel, which causes CA stenosis of various degrees (the so-called internal «negative» remodeling), or, conversely, spreading into a vessel wall (the so-called external «positive» remodeling). There exist various combinations of the above variants [8]. Only a combination of intravascular ultrasound, MSCT, MRI and traditional CA allows to detect external remodeling of a coronary artery wall $[4,13]$. Despite relatively benign development of this morphological type of progression of atherosclerosis, the same changes as in the «traditional» type are possible in such plaques, i.e. those significantly narrowing the lumen. In our study, such methods as intravascular ultrasound, MR-angiography, and MSCT were not used, and life-time morphology of atherosclerotic plaques was not investigated.

6. Myocardial bridge. Normally, the main heart arteries are localized in the epicardium. However, in 5-12\% of patients, a coronary artery may enter the myocardium throughout small duration, passing through the myofibrils and forming the so-called «bridge». Since part of the artery passes through the myofibrils, its lumen's narrowing occurs during each systole. It is obvious that in case of tachycardia, when the time of diastole is decreasing, the total time of a coronary artery segment's spasm increases, which causes myocardial ischemia, to the extent of development of necrosis. The above phenomenon rarely if ever plays a key role in the development of MI, although in some cases it may explain ischemic changes taking place on ECG. In our study, such patients were not identified at all.

7. Vasospasm. Coronary vasospasm had first been described as a probable cause of development of myocardial infarction back in 1966. At a later stage, pathogenetic interrelation between coronary vasospasm and $\mathrm{Ml}$ was proven. It should be emphasized that vasospasm may develop both locally, i.e. in a certain area of a particular artery, and diffusely, it may either migrate along the CA or occur in several parts of various coronary arteries at the same time [8]. In our opinion, in the latter situation, the process of diagnosing MI by way of using ECG is difficult, since, in fact, there is no infarction-related artery at all, or there are several of them («modeling» of

\section{References}

1. Agewall S., Beltrame J. F., Reynolds H. R. [et al.] ESC working group position paper on myocardial infarction with non-obstructive coronary arteries. Eur. Heart. J. 2017;38(3):143-153. doi: 10.1093/ eurheartj/ehw149

2. Bugiardini R., Bairey Merz C. N. Angina with «normal» coronary arteries: a changing philosophy. JAMA 2005;293:477-484. doi: 10.1001/jama.293.4.477

3. Bugiardini R., Manfrini O., De Ferrari G. M. Unanswered questions for management of acute coronary syndrome: risk stratification of patients with minimal disease or normal findings on coronary angiography. Arch. Intern. Med. 2006;166:1391-1395. doi: 10.1001/ archinte.166.13.1391

4. Escolar E., Weigold G., Fuisz A [et al.] New imaging techniques for diagnosing coronary artery disease. CMAJ. 2006:174:487-495 doi: 10.1503/cmaj.050925

5. Gehrie E. R., Reynolds H. R., Chen A. Y. [et al.] Characterization and outcomes of women and men with non-ST-segment elevation myocardial infarction and multi-vessel lesions in coronary arteries). During this study, there were $33.3 \%$ of patients in the group of patients with non-obstructive lesions in coronary arteries that had no changes in ECG, and $30 \%$ of patients with any type of blockade in the His bundle branch system, which also made localization diagnosis complicated. Besides, we failed to define the localization of MI by ECG for $13.0 \%$ of patients with MINOCA. In our opinion, those were exactly the patients in which diffuse and/or migrating coronary vasospasm was the most probable mechanism of development of myocardial necrosis. As for mechanisms of coronary vasospasm, several variants are being currently reviewed: drug addiction, alcoholic intoxication, abrupt calcium-channel blockers withdrawal (verapamil and diltiazem), initial asymptomatic coronary arteries atherosclerosis, endothelial dysfunction [8].

Thus, myocardial infarction with non-obstructive coronary atherosclerosis is a multifactorial phenomenon. In this context, it is very difficult to develop any concerted strategy for the appropriate therapy as to an entire groups such patients. According to the results of our study, patients with MINOCA significantly less often administered antiplatelet agents, and they significantly more often administered ACE inhibitors or sartans as compared to patients with MIOCA. At the same time, patients of both groups administered statins equally as often. According to the data in literature, low doses of aspirin (80-100 mg/day) in patients with minor lesions in coronary arteries and with the vasospastic pathogenetic variant of $\mathrm{MI}$ development do not influence the frequency of recurrent coronary events [9]. Statins use leads to the reduction in death rate on account of any cause in patients with non-obstructive lesions in coronary arteries [6]. According to Olivia Manfrini et al., in patients with non-obstructive lesions in coronary arteries, treatment with beta-blockers was not significantly associated with mortality rates during a year. On the contrary, the use of ACEl was significantly associated with the decrease in death rates during six months in this group of patients [15]. It is worthy of special mention that patients with proven vasospastic pathogenetic mechanism of ischemia and/or necrosis of the myocardium (sampling with ergometrin) should be recommended to administer calcium-channel blockers [10].

Conclusions. According to the results of the conducted study, one patient may have combinations of various pathogenic mechanisms, which makes the process of diagnostics and the selection of adequate treatment more complicated. Further studies of this phenomenon are required, as well as developing concerted strategy of diagnostic approach to the given category of patients.

nonobstructive coronary artery disease: results from the Can Rapid Risk Stratification of Unstable Angina Patients Suppress Adverse Outcomes with Early Implementation of the ACC/AHA Guidelines (CRUSADE) quality improvement initiative. Am. Heart. J. 2009;158:688694. doi: 10.1016/j.ahj.2009.08.004

6. Hwang In-Chang. Statin therapy is associated with lower all-cause mortality in patients with nonobstructive coronary artery disease. Atherosclerosis 2015;239(2):335-342. doi: 10.1016/j.atheroscle-rosis. 2015.01.036

7. Jia H., Abtahian F., Aguirre A. D. [et al.] In vivo diagnosis of plaque erosion and calcified nodule in patients with acute coronary syndrome by intravascular optical coherence tomography. J. Am. Coll. Cardiol. 2013 Nov 5;62(19):1748-1758. doi: 10.1016/j.jacc.2013.05.071

8. Kardasz I., R. De Caterina. Myocardial infarction with normal coronary arteries: a conundrum with multiple aetiologies and variable prognosis: an update. JIM. 2007;261(4):330-348. doi: 10.1111/j.13652796.2007.01788.x 
9. Masanobu I., Koichi K., Koji S. [et al.] Impact of aspirin on the prognosis in patients with coronary spasmwithout significant atherosclerotic stenosis. IJC. 2016;220:328332. doi: 10.1016/j.ijcard.2016.06.157

10. Ohba K., Seigo S., Hitoshi S. [et al.] Microvascular Coronary Artery Spasm Presents Distinctive Clinical Features With Endothelial Dysfunction as Nonobstructive Coronary Artery Disease. J. Am. Heart. Assoc. 2012;1:e002485. doi: 10.1161/JAHA.112.002485

11. Okazaki S., Yokoyama T., Miyauchi K. [et al.] Early statin treatment in patients with acute coronary syndrome: demonstration of the beneficial effect on atherosclerotic lesions by serial volumetric intravascular ultrasound analysis during half a year after coronary event: the ESTABLISH Study. Circulation. 2004;110(9):1061-1068. doi: 10.1161/01.CIR.0000140261.58966.A4

12. Ouldzein H., Elbaz M., Roncalli J. [et al.] Plaque rupture and morphological characteristics of the culprit lesion in acute coronary syndromes without significant angiographic lesion: analysis by intravascular ultrasound. Ann. Cardiol. Angeiol. (Paris) 2012;61:2026. doi: 10.1016/j.ancard.2011.07.011

13. Raggi P., Taylor A., Fayad Z. [et al.] Atherosclerotic plaque imaging: contemporary role in preventive cardiology. Arch. Intern. Med. 2005;165:2345-2353. doi: 10.1001/ archinte. 165.20.2345

14. Reynolds H. R., Srichai M. B., Iqbal S. N. [et al.] Mechanisms of myocardial infarction in women without angiographically obstructive coronary artery disease.

\section{About authors:}

Dyatlov Nikita, MD, CMSc, Assistant of lecturer; e-mail: nick_dv@mail.ru

Lykov Yuriy, Sixth-year student; e-mail: nick_dv@mail.ru

Zhelnov Vladimir, MD, DMSc, Professor of the chair of internal medicine № 2; e-mail: nick_dv@mail.ru

Dvoretsky Leonid, MD, DMSc, Professor, Head of the chair of internal medicine № 2; e-mail: dvoretski@mail.ru
Circulation. 2011;124:1414-1425. doi: 10.1161/ CIRCULATIONAHA.111.026542

15. Roberts James R. Angiotensin-Converting Enzyme (ACE) Inhibitor Angioedema: The Silent Epidemic. AJC. 2012 109 (5):774-775. doi: 10.1016/j.amjcard.2011.11.014

16. Taher $\mathrm{T}, \mathrm{Fu} Y$, Wagner $\mathrm{G}$. [et al.] Aborted myocardial infarction in patients with ST-segment elevation: insights from the Assessment of the Safety and Efficacy of a New Thrombolytic Regiment-3 rial Electrocardiographis Substudy. J. Am. Coll. Cardiol. 2004;44:38-43. doi: 10.1016/j.jacc.2004.03.041

17. Terkelsen C. J., Norgaard B. L., Lassen J. F. [et al.] Potential significance of spontaneous and interventional ST-changes in patients transferred for primary percutaneous coronary intervention: observations from the ST-MONitoring in Acute Myocardial Infarction study (The MONAMI study). European Heart J. 2006;27:267275. doi: 10.1093/eurheartj/ehi606

18. Thygesen K., Joseph S. Alpert, Allan S. Jaffe [et al.] Third Universal Definition of Myocardial Infarction. Circulation. 2012;126:2020-2035. doi: 10.1161/ CIR.0b013e31826e1058

19. Ueda Y., Hinoi T., Matsuo S. [et al.] Intravascular ultrasoundguided coronary artery stenting for spontaneous coronary artery dissection in a case of acute myocardial infarction associated with vasospasm in a non-culprit coronary artery during the hospitalization. Intern. Med. 2006;45:763-767. doi: 10.2169/internalmedicine.45.1688

\title{
DAYTIME SLEEPINESS AND SALIVA HORMONES FLUCTUATIONS IN MEN UNDER TOXIC STRESS
}

\author{
Budkevich R. O., Budkevich E. V., Bobrysheva T. N. \\ North-Caucasus Federal University, Stavropol, Russian Federation
}

\section{АНЕВНАЯ СОНАИВОСТЬ И КОАЕБАНИЯ ГОРМОНОВ В САЮНЕ У АИЦ МУЖСКОГО ПОАА В УСАОВИЯХ ХИМИЧЕСКОГО ЗАГРЯЗНЕНИЯ}

\author{
Р. О. БУАкевич, Е. В. БуАкевич, Т. Н. Бобрышева
}

\section{Северо-Кавказский фелеральный университет, Ставрополь, Российская ФеАерация}

The level of cortisol and testosterone in the morning and evening saliva samples and self-assessment of sleep were studied in adolescents and adults living in low and high chemical pollution regions (according the accumulation of cadmium in the hair). In the conditions of the relatively normal environment the changes in hormones level in form of its rise in the morning and decrease in the evening were noted in both age groups. In the conditions of the toxic stress the average levels of hormones increased, the morning-evening gradient disappeared. These conditions were also associated with an increase in daytime sleepiness. It was concluded that cadmium has negative impact on the sleepwake cycle and the endocrine regulation system. In particular, the changes in hormonal levels indicate the possibility of internal desynchronosis.

Keywords: cortisol, testosterone, desynchronosis, cadmium, daytime sleepiness, sleep-wakefulness cycle

Представлены результаты исследования по самооценке качества сна и определению уровней кортизола и тестостерона в слюне в утренние и вечерние часы у подростков и взрослых мужского пола, проживающих в условиях низкого и высокого химического загрязнения окружающей среды. При низком загрязнении (оценено 